\title{
ДИНАМІКА ЧИСЕЛЬНОСТІ ШКІДНИКІВ ПШЕНИЦІ ОЗИМОЇ В УМОВАХ СУМСЬКОÏ ОБЛАСТІ
}

\author{
Деменко Віктор Михайлович \\ кандидат сільськогосподарських наук, доцент \\ Сумський національний аграрний університет, м. Суми, Україна \\ ORCID: 0000-0002-8264-2802 \\ Vicmix64@ukr.net \\ Голінач Оксана Леонідівна \\ начальник управління фітосанітарної безпеки \\ Головне управління Держпродспоживслужби в Сумській області, м. Суми, Україна \\ hovoruno@gmail.com
}

Ємець Олександр Михайлович кандидат біологічних наук, доцент Сумський національний аграрний університет, м. Суми, Україна ORCID: 0000-0003-1228-1439 yemets_a@ukr.net

Бурдуланюк Алла Олександрівна кандидат сільськогосподарських наук, доцент Сумський національний аграрний університет, м. Суми, Україна ORCID: 0000-0002-9258-7456 burdalla@ukr.net

Рожкова Тетяна Олександрівна кандидат біологічних наук, доцент Сумський національний аграрний університет, м. Суми, Україна ORCID: 0000-0002-0791-9736 rozhkova8@gmail.com

Татаринова Валентина Іванівна кандидат сільськогосподарських наук, доцент Сумський національний аграрний університет, м. Суми, Україна ORCID: 0000-0001-5008-2276 tatarinovasnau@gmail.com

Дослідження проводили у базових господарствах управління фітосанітарної безпеки головного управління Держпродспоживслужби у Сумській області у 2016-2018рр. Методика проведення досліджень була загальноприйнята. На посівах пшениці озимої пошкодження наносять жук-кузька хлібний (Anisoplia austriaca Hrbst.), жук красун (Anisoplia segetum Hrbst.), п'явиия червоногруда (Oulema melanopus L.), п’явиця синя (Oulema lichenis Voet.), блішка хлібна смугаcma (Phyllotreta vittula Redt.), турун хлібний (Zabrus tenebrioides Goeze), клоп гостроголовий (Aelia аситіnata L.), клоп шкідлива черепашка (Eurygaster integriceps Put.), попелиця злакова звичайна (Schizaphis graminum Rond.), mpuпс пшеничний (Haplothrips tritici Kurd.), муха гессенська (Mayetiola destructor Say), муха шведська ячмінна (Oscinella pusilla Mg.).

Жук-кузька розповсюджений у Сумській області повсюдно, а жук красун має більше поширення у зоні Полісся. Личинки хлібних жуків заселяли у 2016 р. 22,7 \%, у 2017 р. - 20,3 \%, у 2018 р. - 23,9 \% площ пшениці озимої. Середня чисельність личинок жуків хлібних у 2016, 2018 рр. була 0,7 екз./M², у 2017 р. - 0,9 екз./M². Найбільщ розповсюдженими на посівах пшениці були імаго жуків хлібних, які у фразу молочно-воскової стиглості зерна обгризали та виштовхували зерна з колосу. Жуки хлібні у фразу молочної стиглості зерна заселяли у 2016 р. 85,2 \%, у 2017 р. - 84,6 \%, у 2018 р. - 72,4 \% обстежених площ пшениці озимої. Чисельність імаго жуків хлібних була

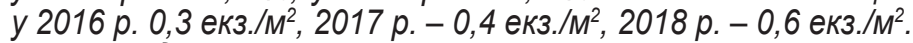

Внаслідок живлення на зерні личинок та клопів, що окрилилися елії гостроголової та клопа шкідливої черепашки, погіршуються хлібопекарські та харчові якості борошна, а також посівні якості зерна. Клопи хлібні заселяли у 2016 р. 24,1 \%, у 2017 р. - 37,1\%, у 2018 р. - 42,3 \% обстежених площ пшениці озимої. Середня чисельність клопів на посівах пшениці озимої була 0,7 екз./M².

У 2016-2017 рр. чисельність личинок мухи шведської в осінній період була 1,4 екз./м², а у 2018 р. зросла до

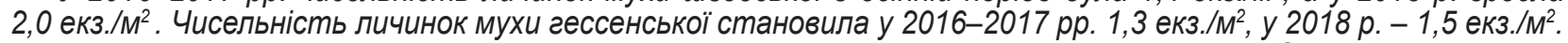

Ключові слова: пшениця озима, жук-кузька, жук красун, елія гостроголова, клоп шкідлива черепашка, муха гессенська, чисельність шкідників, відсоток заселених площ шкідниками.

DOI https://doi.org/10.32845/agrobio.2021.2.2 
Вступ. Виробництво зерна в Україні становило у 2008 р. 53,3 млн. т., 2009 р. - 46,0 млн. т., 2011 р. - 56,7 млн. т., у 2013-2017 pp. - 60,1-64,2 млн. т., у 2018-2019 рр. більше 70 млн. т. Нині наша країна забезпечує 3 \% світового виробництва зерна і більш як 10 \% світового експорту (Borzyh \& Krut', 2019). Україна за останні роки значно збільшила експорт сільськогосподарської продукції, а основою експорту є зерно пшениці. У Сумській області площа посівів пшениці озимої становила у 2008 р. 206,85 тис. га, 2009 р. $-225,2$ тис. га, 2010 р. $-228,3$ тис. га, 2011 р. 212,1 тис. га, 2012 р. - 187,8 тис. га (Demenko et al., 2016). Але у 2016 р. посівні площі пшениці склали 200,7 тис. га, 2017 р. - 179,3 тис. га, 2018 р. - 157,8 тис. га. Для сівби пшениці озимої зменшилися площі кращих попередників. Кормові культури вирощувалися у 2016 р. на площі 39,4 тис. га, 2017 р. $-31,6$ тис. га, 2018 р. - 29,85 тис. га. Тому в господарствах Сумської області часто попередником пшениці озимої був соняшник, площі якого зросли у 2016 р. до 169,2 тис. га, 2017 р. - 188,32 тис. га, 2018 р. - 202,75 тис. га. Поряд з тим, значно збільшилися площі вирощування кукурудзи на зерно. У 2016 р. кукурудзу висівали на площі 218,85 тис. га, 2017 р. 305,34 тис. га, 2018 р. - 351,5 тис. га. Така структура посівних площ призводить до збільшення чисельності окремих спеціалізованих та багатоїдних шкідників. В умовах Правобережного Лісостепу ентомокомплекс пшениці озимої представлений 55 видами шкідливих комах, у тому числі: твердокрилі (Coleoptera) - 14 видів, двокрилі (Diptera) 11 видів, напівтвердокрилі (Hemiptera) - 11 видів, рівнокрилі (Homoptera) - 7 видів, лускокрилі (Lepidoptera) - 5 видів, війчастокрилі (Thysanoptera) - 4 види, перетинчастокрилі (Hymenoptera) - 2 види, прямокрилі (Orthoptera) - 1 вид (Strigun \& Suddenko, 2016). За результатами досліджень В. С. Медвідь за період 2017-2019рр. у Правобережному Лісостепу України на пшениці озимій виявлено 32 види фітофагів, що належать до 17 родин із 7 рядів комах (Medvid', 2020). У Центральному Лісостепу України комахи-фітофраги були представлені 54 видами 322 родин. У таксономічній структурі шкідників домінували представники рядів: твердокрилі (Coleoptera) - 18 видів, двокрилі (Diptera) - 11 видів, напівтвердокрилі (Hemiptera) - 8 видів, рівнокрилі (Homoptera) - 8 видів, лускокрилі (Lepidoptera) 5 видів (Mostov'jak et al., 2020). Крім того, за останні десять років зростає температура повітря, що також впливає на посилене розмноження і міграцію комах-фрітофагів у регіони України, які були для них несприятливими через обмежену кількість тепла і суму ефективних температур, необхідну для розвитку. Потепління позначилося на структурі видового складу ентомокомплексу пшениці озимої в Лісостепу України через збільшення чисельності і шкідливості опомізи, клопів-черепашок, пшеничного трипса та хлібних жуків (Borzih \& Fedorenko, 2016). М. С. Корнійчук відмічає зростання чисельності і шкодочинності на посівах зернових культур мухи опомізи, мухи пшеничної, трипса пшеничного та хлібних жуків (Kornijchuk, 2019). Встановлено циклічність спалахів масового розмноження хлібного жукакузьки, залежно від величини сонячної активності та розроблено алгоритми оцінки стану популяцій і ступеня загрози для посівів личинок та імаго хлібних жуків (Krut', 2021).

За останні роки змінилася і технологія вирощування пшениці озимої, особливо використання мінеральних добрив. Як зазначає Т. С. Віннічук разом із співавторами (Vinnichuk et al., 2016) системи удобрення пшениці впливають на чисельність злакових трипсів. Ресурсоощадні технології використання азотних добрив та інсектицидів, які досліджували В. В. Сахненко та Д. В. Сахненко (Sahnenko \& Sahnenko, 2018) підтверджують зміну чисельності хлібних жуків, шведської мухи, злакових клопів. У Західному Лісостепу України органо-мінеральні системи удобрення в поєднанні з вапнуванням впливали на зменшення чисельності злакових мух, п'явиць, пшеничних трипсів та хлібних клопів (Pristac'ka, 2021). Тому вивчення динаміки шкідників пшениці озимої $€$ актуальним, а використання інсектицидів у технології вирощування культури $є$ важливим заходом захисту.

Мета дослідження - проаналізувати видовий склад шкідників пшениці озимої для вчасного виявлення та попередження втрат урожаю зерна.

Матеріали і методи досліджень. Дослідження за динамікою заселення посівів пшениці озимої, чисельністю спеціалізованих шкідників на рослинах проводили у базових господарствах управління фітосанітарної безпеки головного управління Держпродспоживслужби в Сумській області у 2016-2018рр. Методика проведення досліджень була загальноприйнята (Dolja et al., 2004). Для визначення чисельності злакових клопів, імаго хлібних жуків обліки проводили на 16 ділянках

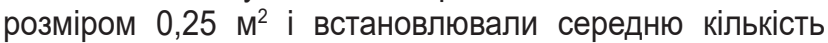
шкідників на м². Чисельність личинок хлібних жуків обліковували методом ґрунтових розкопок на ділянках розміром 0,25 м² та визначали їх середню кількість на м². Для обліку личинок шведської, гессенської мухи восени викопували рослини на відрізку 0,5 м в 16 місцях поля. В лабораторії підраховували личинок, пупарії мух та їх середню чисельність на ${ }^{2}$.

Результати. У Сумській області на посівах пшениці озимої пошкодження наносять жук-кузька хлібний (Anisoplia austriaca Hrbst.), жук красун (Anisoplia segetum Hrbst.), п'явиця червоногруда (Oulema melanopus L.), п'явиця синя (Oulema lichenis Voet.), блішка хлібна смугаста (Phyllotreta vittula Redt.), турун хлібний (Zabrus tenebrioides Goeze), клоп гостроголовий (Aelia acuminata L.), клоп шкідлива черепашка (Eurygaster integriceps Put.), попелиця злакова звичайна (Schizaphis graminum Rond.), трипс пшеничний (Haplothrips tritici Kurd.), муха гессенська (Mayetiola destructor Say), муха шведська ячмінна (Oscinella pusilla Mg.).

Але найбільш розповсюдженими і шкодочинними $€$ жуки хлібні. Жук-кузька хлібний (Anisoplia austriaca Hrbst.) розповсюджений в Сумській області повсюдно, а жук красун (Anisoplia segetum Hrbst.) має більше поширення у зоні Полісся. Личинки жуків хлібних пошкоджують корені пшениці. За даними рис. 1 відмічаємо, що під час проведення обліків восени у 2016 р. личинки шкідників були виявлені на площі 29,5 тис. га з 129,7 тис. га обстеженої, а відсоток заселених площ склав $22,7 \%$. У 2017 р. було обстежено 121,2 тис. га посівів пшениці озимої, а личинки були виявлені на площі 24,6 тис. га, що становить 20,3 \% заселених площ. У 2018 р. личинки хлібних жуків зустрічалися на 27,5 тис. га, відсоток заселених площ склав 23,9 \% з 115,3 тис. га обстежених посівів пшениці 
озимої. Середня чисельність личинок шкідників у 2016,

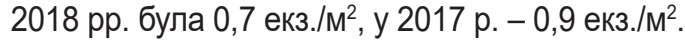

Для попередження зрідження посівів від пошкодження личинками хлібних жуків потрібно проводити передпосівну обробку насіння препаратами: Вітакс ТН, 0,5 2,5 л/т, Грінфрорт Конфрі, ТН, 0,4 - 0,6 л/т, Даліла 600 TH, 0,5 - 1,0 л/т, Імідор Про, к.С., 1,0 л/т, Імісід БТ, ТН, 0,4 - 0,5 л/т, Інітер 600, ТН, 0,5 - 1,0 л/т, Ін Сет, ВГ, 0,25 - 0,75 л/т, Койот, КС, 0,5 - 0,75 л/т, Командор Екстра, ТН, 0,3 - 0,6 л/т, Команч WG, ВГ, 0,5 л/т, Контадор Макси, ТH, 0,3 - 0,75 л/т, Лорд, ВГ, 0,25 - 0,75 л/т, Матадор Макс, ТН, 0,5 - 0,8 л/т, Нупрід 600, ТН, 0,5 - 1,6 л/т, Пікус 600, ТН, 0,3 - 1,6 л/т, Сідопрід ТН, 0,5 - 0,85 л/т, Табу, КС, 0,4 - 0,5 л/т, Гаучо Плюс 466 FS, TH, 0,3 - 0,8 л/т, Кайзер ТH, 0,4 - 0,5 л/т, Круїзер 350 FS, т.к.с., 0,4 - 0,5 л/т, Командор Гранд, ТН, 0,3 - 1,0 л/т, Тримбіта, ТН, 0,75 - 1,0 л/т, Пентафорс 322 FS, TH, 1,5 - 2,0 л/т, Прем'єр Профрі, РН, 1,5 - 2,0 л/т (Perelik pestycydiv i agrohimikativ..., 2018). Про необхідність обробки насіння та захисту сходів пшениці озимої від совок підгризаючих, жужелиці хлібної, мух злакових, попелиць вказують Т. Мостіпан та О. Гайденко (Osinnij zahyst..., 2020)
Найбільш розповсюдженими на посівах пшениці були імаго хлібних жуків (рис. 2). У фазу молочно-воскової стиглості зерна жуки обгризають зерна, а у фазу повної стиглості виштовхують зерна з колосу. Жуки особливо інтенсивно пошкоджують рослини у сонячні дні за температури вище $20,0^{\circ} \mathrm{C}$. Шкідники заселяють посіви з країв поля і поступово, за збільшення їх чисельності, розповсюджуються у середину поля. Жук-кузька і жук красун у фазу молочної стиглості зерна у 2016 р. були виявлені на площі 2,3 тис. га з 2,7 тис. га обстеженої, а відсоток заселених площ становив 85,2 \%. Чисельність шкідника була 0,3 екз./м². у 2017 р. чисельність хлібних жуків збільшилася до 0,4 екз./м². 3 обстеженої площі 2,6 тис. га фітофаги були виявлені на 2,2 тис. га, а відсоток заселених площ склав 84,6 \%. Найбільш висока чисельність шкідників на посівах спостерігалася у 2018 р. і становила 0,6 екз./м². Але відсоток заселених площ був дещо нижчий, порівняно $з$ попередніми роками (72,4 \%). Хлібні жуки були виявлені на площі 2,1 тис. га з 2,9 тис. га обстежених посівів.

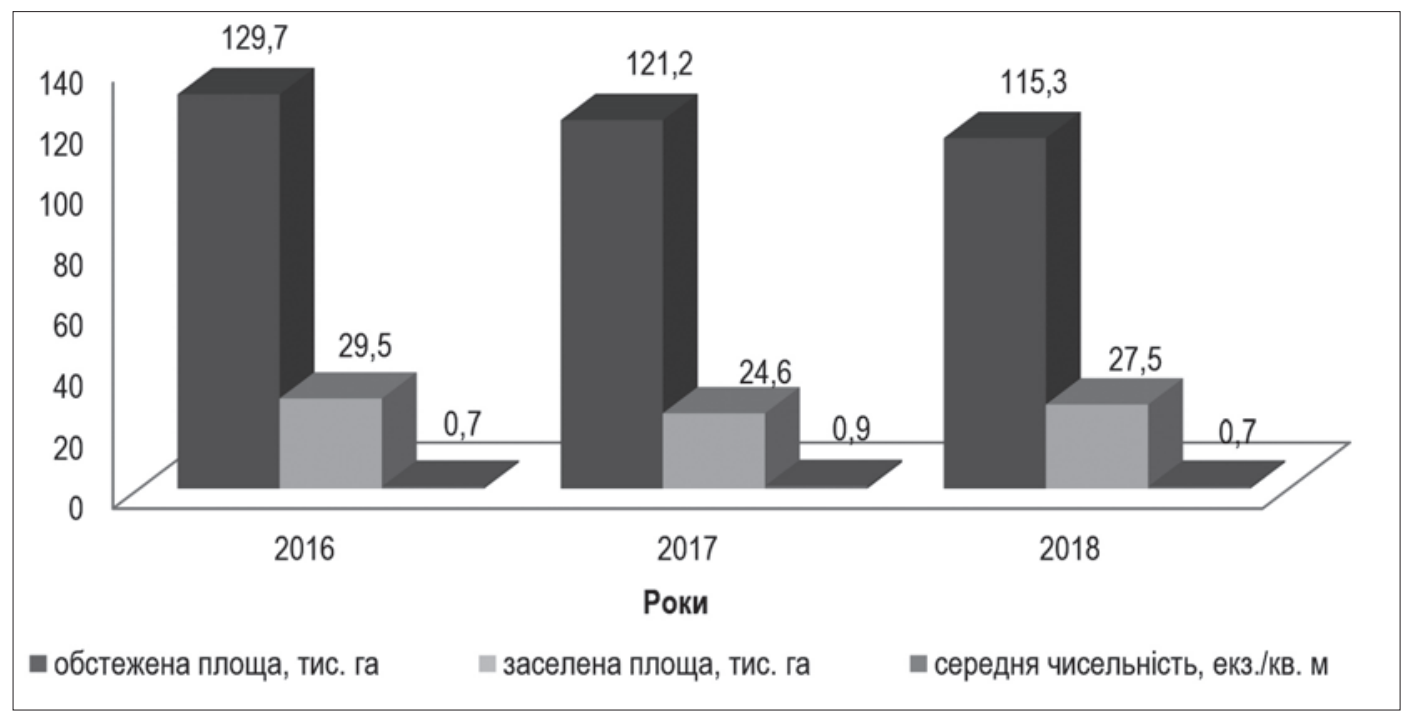

Рис. 1. Заселена площа пшениці озимої, чисельність личинок хлібних жуків восени

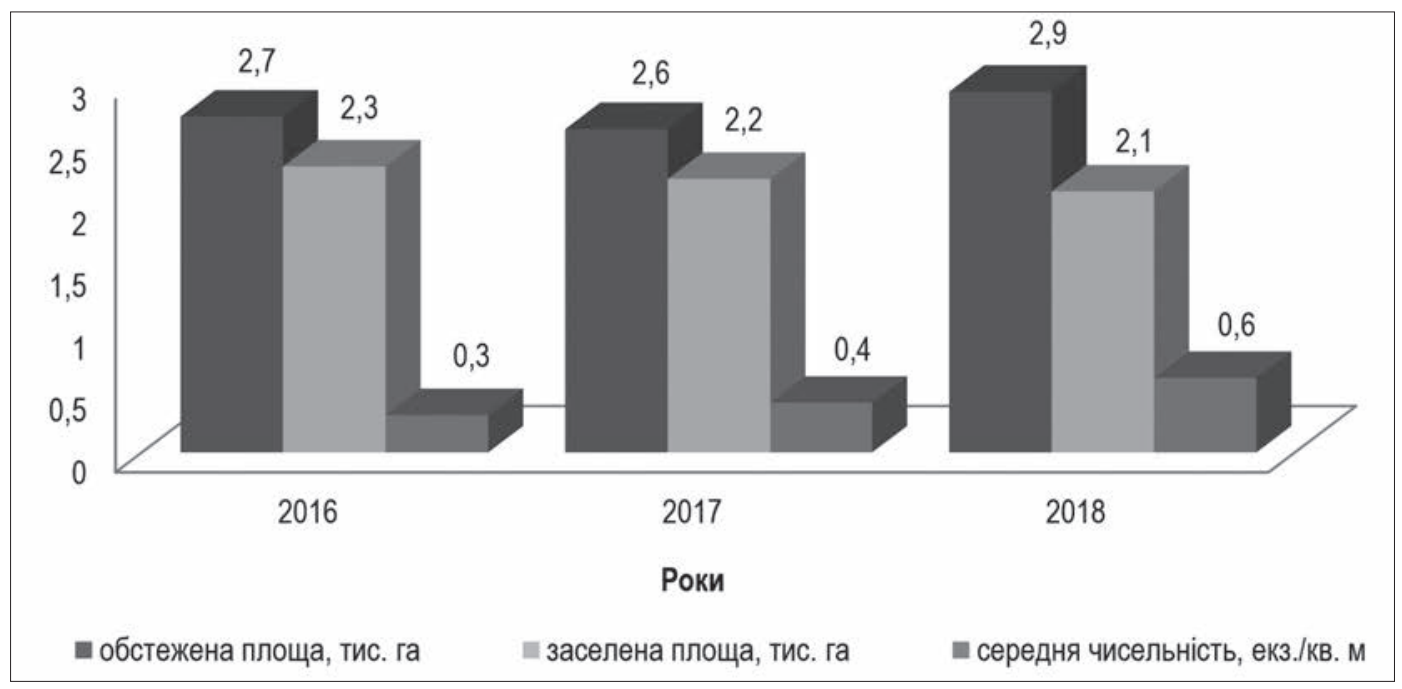

Рис. 2. Заселена площа пшениці озимої, чисельність хлібних жуків у фазу молочної стиглості 
В умовах Сумської області, особливо у південній частині лісостепової зони за останні роки поступового поширення набувають хлібні клопи: гостроголовий (Aelia acuminata L.), шкідлива черепашка (Eurygaster integriceps Put.). Після виходу з місць зимівлі у період додаткового харчування імаго клопів роблять наколи на стеблах, висмоктують сік. Пошкоджені рослини засихають, а у період колосіння утворюють повну або часткову білоколосість. Личинки живляться соком листя, потім колоскових лусочок, остей, зерен. Внаслідок живлення на зерні личинок та клопів, що окрилилися, погіршуються хлібопекарські та харчові якості борошна, а також посівні якості зерна. За даними рис. 3 відмічаємо, що у 2016 р. було обстежено 63,2 тис. га посівів пшениці озимої у фазу наливу зерна. Клопи хлібні були виявлені на площі 15,2 тис. га, що становить 24,1 \% від обстеженої площі. Чисельність клопів була 0,7 екз./м². У 2017 р. при обліку шкідники були на площі 14,8 тис. га з загальної обстеженої - 39,9 тис. га, а відсоток заселених площ склав $37,1 \%$. Середня чисельність хлібних клопів становила 0,7 екз./м². За даними обліків 2018 р. було обстежено
47,1 тис. га, а шкідники були виявлені на площі пшениці озимої 19,9 тис. га. Заселена клопами хлібними площа склала 42,3 \%. Середня чисельність шкідників була на рівні попередніх років і становила 0,7 екз./м². Отже, за роки досліджень відсоток заселених площ елією гостроголовою і клопом шкідливої черепашки зріс з 24,1 \% у 2016 р. до 42,3 \% у 2018 р., але середня чисельність клопів на посівах пшениці озимої була 0,7 екз./м².

Личинки мухи шведської проникають у середину стебла, де живляться тканиною центрального листка та зачатком колоса. Внаслідок цього листок засихає, і згодом рослина гине. У 2016-2017 рр. чисельність личинок шведської мухи в осінній період була 1,4 екз./м², а у 2018 р. зросла до 2,0 екз./м² (рис. 4).

Личинки мухи гессенської живляться у піхві листків і у разі пошкодження головних стебел восени або до виходу в трубку ріст центрального листка припиняється, пошкоджені стебла гинуть, а у період виходу в трубку стебла неправильно згинаються і вилягають. Чисельність личинок мухи гессенської була менша ніж шведської і ста-

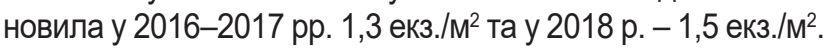

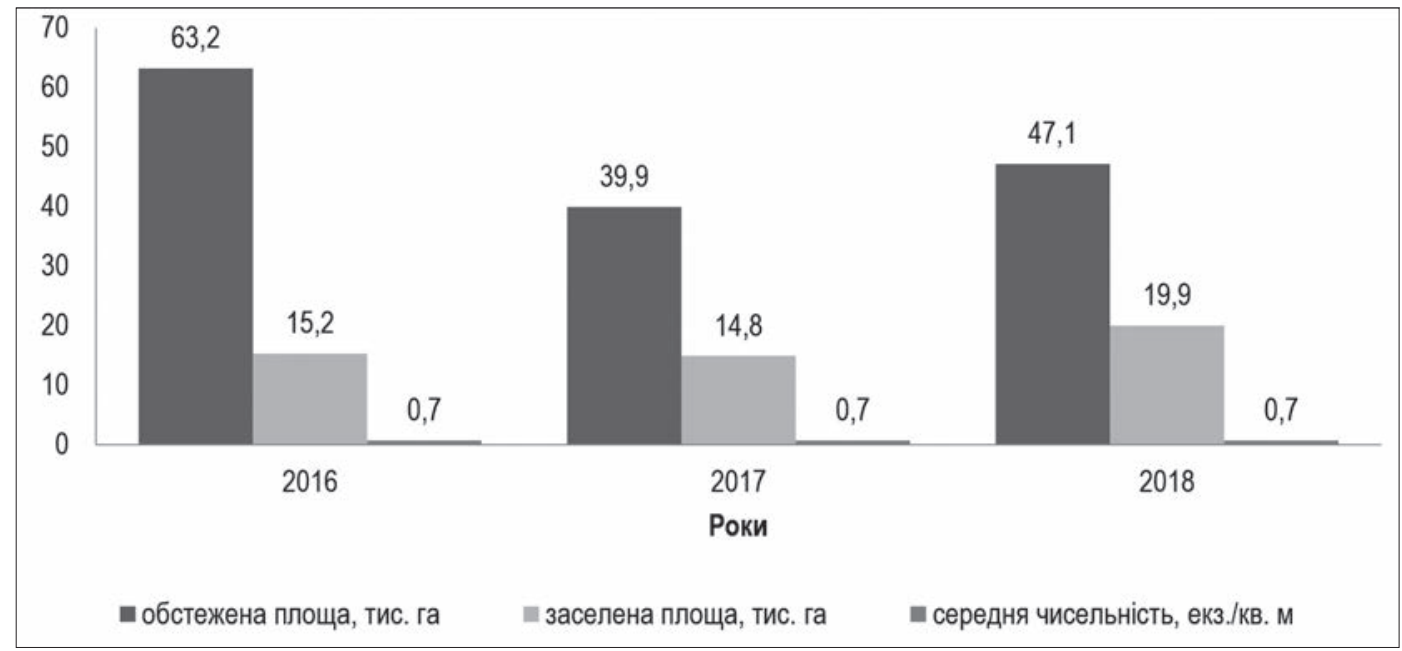

Рис. 3. Заселена площа пшениці озимої, середня чисельність хлібних клопів у фазу наливу зерна

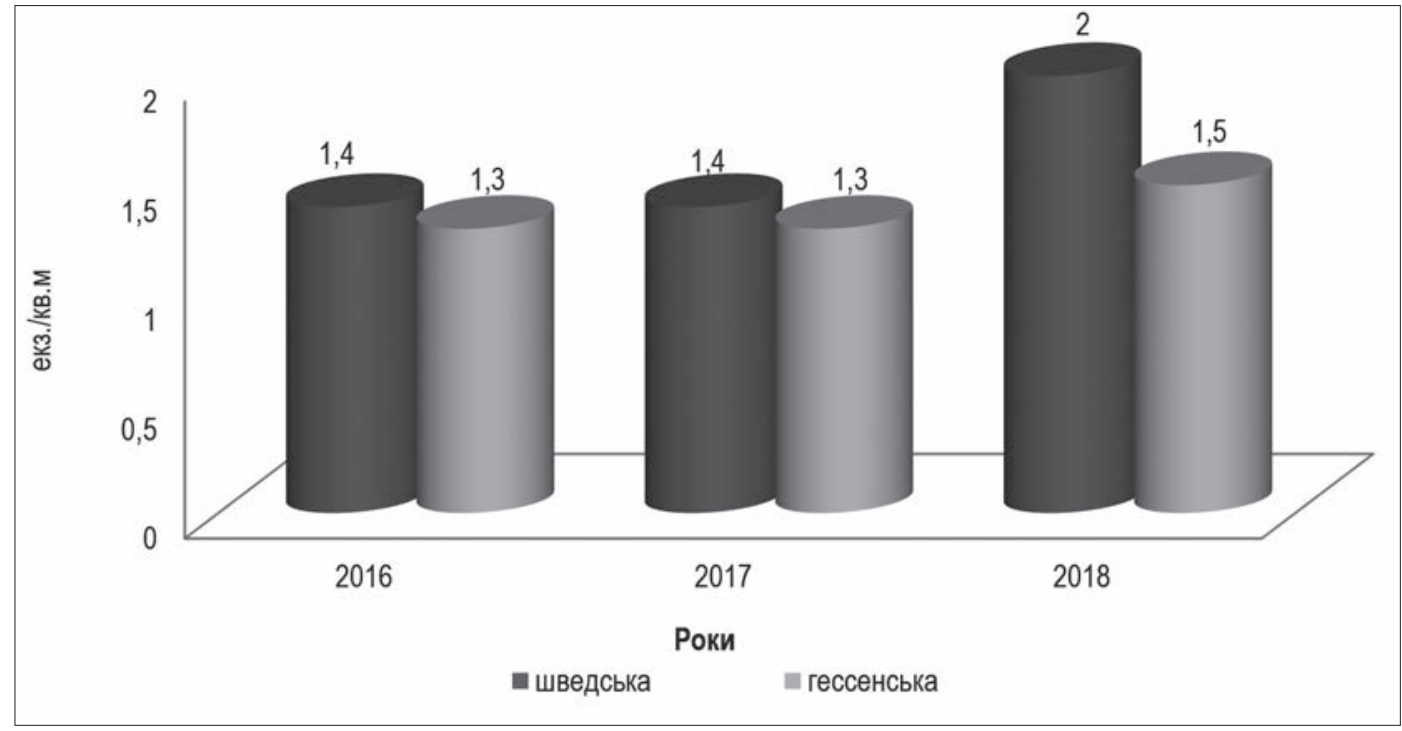

Рис. 4. Чисельність мух шведської і гессенської в осінній період на посівах пшениці озимої 
Заселеність посівів пшениці озимої за 2016-2018 рр. була різною по видах шкідників та роках (табл. 1). Імаго жуків хлібних заселяли від 85,2 \% у 2016 р. до 72,4 \% площ у 2018 р. Заселеність личинками жуків хлібних становила у 2016 р. 22,7 \%, у 2017 р. - зменшилася до 20,3 \%, у 2018 р. - зросла до 23,9 \%. Істотне збільшення заселення площ пшениці озимої відбувалося клопами хлібними з 24,1 \% у 2016 р., до 37,1 \% - у 2017 р. та $42,3 \%$ - у 2018 p.

Таблиця 1

Відсоток заселених площ пшениці озимої шкідниками

\begin{tabular}{|c|c|c|c|}
\hline $\begin{array}{c}\text { Роки } \\
\text { досліджень }\end{array}$ & $\begin{array}{c}\text { Личинки } \\
\text { жуків } \\
\text { хлібних }\end{array}$ & $\begin{array}{c}\text { Імаго жуків } \\
\text { хлібних }\end{array}$ & $\begin{array}{c}\text { Клопи } \\
\text { хлібні }\end{array}$ \\
\hline 2016 & 22,7 & 85,2 & 24,1 \\
\hline 2017 & 20,3 & 84,6 & 37,1 \\
\hline 2018 & 23,9 & 72,4 & 42,3 \\
\hline $\mathrm{HIP}_{05}$ & 1,4 & 1,7 & 1,5 \\
\hline
\end{tabular}

Обговорення. Враховуючи перевищення шкідниками економічного порогу шкодочинності на посівах пшениці, використання інсектицидів $€$ обов'язковим прийомом в технології вирощування (Suchasnyj zahyst zernovyh..., 2019; Shkidnyky i hvoroby..., 2019). Інститутом захисту рослин НААН України розроблені зональні інтегровані системи зернових культур (Krut' \& Gavriljuk., 2020). Відповідно, управлінням фітосанітарної безпеки Головного управління Держпродспоживслужби у Сумській області розроблений «Прогноз фрітосанітарного стану агроценозів та рекомендації щодо захисту культурних рослин від шкідників, хвороб та бур'янів у господарствах Сумської області в 2021 році» (Golinach et al., 2021). У фразі сходів - початок кущення на добре розвинених посівах ранніх строків сівби та за теплої погоди для захисту посівів від попелиць злакових (100-400 особин на м²), мух шведської та гессенської (40-50 імаго злакових мух на 100 змахів сачком, або при 10 \% пошкоджених стебел), совок підгризаючих (понад 2-3 гусениці на м²), туруна хлібного (1-3 личинки на м²) проводять обприскування (крайове, вибіркове в осередках розмноження шкідників або суцільне) посівів інсектицидами: Альфагард 100, к.е., 0,1-0,15 л/га, Бестселлер Турбо 200, КС, 0,05-0,08 л/га, Бетадим, КЕ, 0,15-0,5 л/га, БІ-58 новий, к.е., 1,5 л/га, Данадим Мікс, КЕ, 1,0 л/га, Борей, КС, 0,16 л/га, Дурсбан 480, к.е., 1,0-1,5 л/га, Енжіо 247 SC, КС, 0,25-0,4 л/га, Карате Зеон 050, SC, СK, 0,30 л/га, Пірінекс Супер, КС, 1,0 л/га, Сумітіон, KE, 0,6-1,5 л/га (Perelik pestycydiv i agrohimikativ..., 2018; Zahyst ozymoi' pshenyci..., 2020). Г. Косилович та Ю. Голячук (Kosylovych \& Goljachuk, 2019) при проведенні досліджень отримали високу ефективність інсектицидів Енжіо 247 SC, КС та Карате Зеон 050, SC, СК. В умовах східної частини Лісостепу України інсектицидні протруйники забезпечили зниження пошкодження пагонів личинками злакових мух до 1,0-2,4 \% (Kuz'menko et al., 2016). Використання сумішей препаратів у фразу сходи кущення підвищує технічну ефективність інсектицидів до 94-98 \% і сприяє отриманню приросту врожаю до 0,4 т/га в усіх ґрунтово-кліматичних зонах України (Varchenko et al., 2017).

У фразу виходу в трубку для захисту від клопівчерепашок (не менше двох особин на м²), мух шведської, гессенської (30-40 на 100 змахів сачком) застосовують інсектициди: Дестрой, КС, 0,1 л/га, Антиколорад, КС, 0,5 л/га, Блискавка, КЕ, 0,1-0,15 л/га, Фастак, КЕ, 0,1-0,15 л/га, Децис Профрі 25 WG, ВГ, 0,04 кг/га, Маврік, EВ, 0,15-0,2 л/га, Сумі альфа, КЕ, 0,3 л/га (Perelik pestycydiv i agrohimikativ..., 2018). Н. М. Шахова та Н. І. Коцюрубенко відмічають проти клопа черепашки технічну ефективність 92,7 \% інсектициду Децис Профрі 25 WG, ВГ, а Сумі альфа, KE - 93,8 \% (Shahova \& Kocjurubenko, 2012). Ефрективність близько $100 \%$ у боротьбі зі шкідниками забезпечує інсектоакаріцид Кінфос, KЕ, 0,3 л/га у поєднанні з гербіцидом нового покоління Примадона, 0,8 л/га (Pisarenko et al., 2021).

Для запобігання відчутним втратам врожаю від попелиць злакових (10-30 особин на стебло), жуків хлібних (5-6 жуків на м²), трипсів злакових (40-50 особин на колос), клопа-черепашки та інших видів клопів (2-6 особин на м²) у фразу формування-наливання зерна проводять обприскування посівів: Борей, КС, 0,1-0,14 л/га, Грінфорт ІЛ 200, КС, 0,5 л/га, Оперкот Акро, КС, 0,05 л/га, Бунчук, КЕ, 1,2 л/га, Вантекс Мк.с., 0,06-0,07 л/га, Велес, КС, 0,3-0,4 л/га, Протеус 110 OD, МД, 0,75-1,0 л/га, ВЕПО, KE, 0,3 л/га, Децис f-Люкс 25 EC, КЕ, 0,3-0,4 л/га, Драгун, 0,8-1,2 л/га, Карате Зеон 050 SC, СК, 0,15-0,25 л/га, Коннект 112,5 SC, КС, 0,4-0,5 л/га, Нурел Д, к.е., 0,75-1,0 л/га, Суперкіл 440, КЕ, 0,75 л/га (Perelik pestycydiv i agrohimikativ..., 2018). О. А., Демидов та Т. І. Муха в умовах Миронівського інституту пшениці імені В. М. Ремесла НААН України рекомендують обов'язково проводити інсектицидну обробку посівів у фазу молочно-воскової стиглості зерна (Demidov \& Muha, 2019). Дослідження в Інституті захисту рослин НААН України встановили показник резистентності популяції звичайної злакової попелиці до інсектициду Децис Профрі, в.г. 10,1, Карате 050 ЕС, к.е. - 8,2, БІ 58 новий, 40 \% к.е. - 6,4, Конфідор 200, р.к. - 1,6 (Sekun et al., 2019). Для зниження резистентності комах до шкідників у період вегетації необхідно застосовувати суміші препаратів на основі д. р. лямбда-цигалотрин + тіаметоксам, хлорпірифос + циперметрин, дельтаметрин + тіаклоприд та мають високу технічну ефективність. (Sahnenko \& Sahnenko, 2020). Причому ТОВ «УКРАВІТ АГРО» рекомендує проводити інсектицидний захист для низького, середнього, високого рівня інтенсифікації виробництва залежно від фінансових можливостей господарств і запланованої урожайності зерна (AgroMatematyka, 2017).

Висновки. У базових господарствах управління фрітосанітарної безпеки головного управління Держпродспоживслужби у Сумській області у 2016-2018 рр. на посівах пшениці озимої найбільш розповсюдженими були імаго хлібних жуків. У фазу молочної стиглості зерна жуки хлібні заселяли у 2016 р. 85,2 \%, 2017 р. 84,6 \%, 2018 р. - 72,4 \% обстежених площ пшениці озимої. Чисельність імаго становила у 2016 р. 0,3 екз./м²,

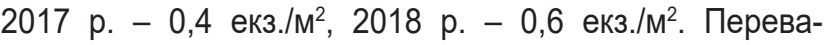


жаючими видами хлібних жуків були кузька хлібний (Anisoplia austriaca Hrbst.) і в меншій мірі - жук красун (Anisoplia segetum Hrbst.). Заселена площа личинками жуків хлібних була у 2016 р. 22,7 \%, 2017 р. - 20,3 \%, 2018 р. - 23,9 \%. Середня чисельність личинок у 2016,

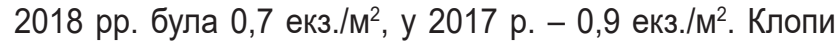
хлібні у фазу наливу зерна заселяли у 2016 р. 24,1\%, 2017 р. - 37,1\%, 2018 р. - 42,3 \% обстежених площ пшениці озимої, а середня чисельність клопів була 0,7 екз./м².
Чисельність личинок мухи шведської в осінній період у 2016-2017 рр. була 1,4 екз./м², а у 2018 р. зросла до 2,0 екз./ $\mathrm{M}^{2}$ та личинок мухи гессенської становила у 2016-2017 рр. 1,3 екз./м², у 2018 . - 1,5 екз./м².

Для зменшення втрат врожаю від пошкодження шкідниками потрібно проводити передпосівну обробку насіння інсектицидними препаратами та обприскування посівів у фази сходів - початок кущення, виходу в трубку, формування-наливання зерна пшениці озимої.

\section{Бібліографічні посилання:}

1. AgroMatematyka: Tehnologija vyroshhuvannja ozymoi' pshenyci. [AgroMathematics: Technology of growing winter wheat]. (2017). URL: https://ukravit.ua/uk/agromatematyka-tehnologiya-vyroshhuvannya-ozymoyi-pshenytsi/ (in Ukrainian).

2. Borzyh, O. I., \& Krut', M. V. (2019). Baza danyh innovacijnyh rozrobok iz zahystu zernovyh kul'tur v Ukrai'ni [Database of innovative developments in the protection of grain crops in Ukraine]. Zahyst i karantyn roslyn, 65, 3-16. doi: 10.36495/1 606-9773.2019.65.3-16 (in Ukrainian).

3. Borzih, O. I., \& Fedorenko, V. P. (2016). Suchasni problemi fitosanitarnogo stanu agrocenoziv v Ukraïni [Modern problems of phytosanitary condition of agrocenoses in Ukraine]. Zahist i karantin roslin, 62, 3-17 (in Ukrainian).

4. Golinach, O. L., Vlasenko, V. A., Demenko, V. M., Hil'ko, N. V., Proshhenko, O. V., \& Tkachenko, V. A. (2021). Prognoz fitosanitarnogo stanu agrocenoziv ta rekomendaciï shhodo zahistu kul'turnih roslin vid shkidnikiv, hvorob ta bur'janiv u gospodarstvah Sums'koï oblasti v 2021 roci. [Forecast of phytosanitary condition of agrocenoses and recommendations for protection of cultivated plants from pests, diseases and weeds in farms of Sumy region in 2021]. Golovne upravlinnja Derzhprodspozhivsluzhbi u Sums'kij oblasti. Sumi, 117 (in Ukrainian).

5. Demenko, V. M., Govorun, O. L., Vlasenko, V. A., Jemec', O. M., \& Hil'ko, N. V. (2016). Dynamika chysel'nosti osnovnyh shkidnykiv zernovyh kul'tur v umovah pivnichno-shidnogo Lisostepu Ukrai'ny. [Dynamics of the number of the main pests of grain crops in the conditions of the North-Eastern Forest-Steppe of Ukraine]. Visnyk Sums'kogo NAU. Serija «Agronomija i biologija». 2(31), 50-55 (in Ukrainian).

6. Demidov, O. A., \& Muha, T. I. (2019). Kontrol' chisel'nosti hlibnih klopiv u agrocenozi pshenici. [Control of the number of bedbugs in the wheat agrocenosis] Propozicija: Informacijnij shhomisjachnik. Ukraïns'kij zhurnal z pitan' agrobiznesu. TOV "Kompanija "Junivest Marketing", Kiïv, 6, 102-104 (in Ukrainian)..

7. Dolja, M. M., Pokozij, J. T., Mamchur, R. M., Dolja, L. I., Mel'nyk, B. V., Dmytrijeva, O. Je., Homenko, I. I., Bondarjeva, L. M., \& Gumenjuk, L. V. (2004). Fitosanitarnyj monitoring. [Phytosanitary monitoring]: posibnyk dlja stud. agron. spec. vyshh. zakl. / za red. M. M. Doli ta J. T. Pokozija. K.: DOD NNC «Instytut agrarnoi' ekonomiky», 291 (in Ukrainian).

8. Kornijchuk, M. S. (2019). Fitosanitarnij stan agrocenoziv v umovah zmini klimatu ta shljahi jogo pokrashhannja. Zemlerobstvo. [Phytosanitary condition of agrocenoses in the conditions of climate change and ways of its improvement], 2(97), 45-57 (in Ukrainian).

9. Kosylovych, G., \& Goljachuk, Ju. (2019). Zahyst pshenyci ozymoi' vid shkidnykiv i hvorob. [Protection of winter wheat from pests and diseases]. Visnyk L'vivs'kogo NAU. Serija «Agronomija», 23, 159-163 (in Ukrainian).

10. Krut', M. V. (2021) Innovaciï z prognozuvannja fitosanitarnogo stanu agrocenoziv. [Innovations for forecasting the phytosanitary condition of agrocenoses]. Ricerche scientifiche e metodi della loro realizzazione: esperienza mondiale e

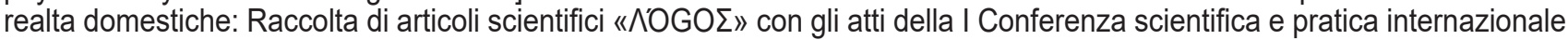
(T. 1), Bologna, May 14, Bologna-Vinnytsia: Associazione Italiana di Storia Urbana \& Piattaforma scientifica europea, 91-95. doi: 10.36074/logos-14.05.2021.v1.28 (in Italiana).

11. Krut', M. V., \& Gavriljuk, L. L. (2020). Baza danih innovacijnih rozrobok iz zahistu zernovih kul'tur v Ukraïni. [Database of innovative developments in the protection of grain crops in Ukraine]. The 10th International scientific and practical conference "Topical issues of the development of modern science" (June 4-6, 2020) Publishing House "ACCENT", Sofia, 384-389 (in Bulgarian).

12. Kuz'menko, N. V., Popov, S. I., Lytvynov, A.Je., Popova, K. M., Glubokyj, O. M., Malahov, D. Ju., \& Olejnikov Je. S. (2016). Systema zahystu zernovyh kolosovyh kul'tur vid hvorob ta shkidnykiv v umovah shidnoi' chastyny Lisostepu Ukrai'ny. [The system of protection of cereals from diseases and pests in the eastern part of the Forest-Steppe of Ukraine]. NAAN, In-t roslynnyctva im. V. Ja. Jur'jeva NAAN, Charkiv, 24 (in Ukrainian).

13. Medvid', V. S. (2020). Entomofauna pshenici ozimoï u Pravoberezhnomu Lisostepu Ukraïni. [Entomofauna of winter wheat in the Right-Bank Forest-Steppe of Ukraine]. Visnik agrarnoï nauki Prichornomor'ja, 3, 96-104 (in Ukrainian). doi: 1 $0.31521 / 2313-092 X / 2020-3(107)-12$

14. Mostov'jak, I. I, Dem'janjuk, O. S., Lisovij, M. M. (2020). Ekologichna struktura shkidlivogo entomokompleksu agrocenoziv zernovih zlakovih kul'tur Central'nogo Lisostepu Ukraïni. [Ecological structure of the harmful entomocomplex of agrocenoses of grain cereals of the Central Forest-Steppe of Ukraine]. Agroekologichnij zhurnal. 2. 31-39. DOI: https://doi.org/10.33730/2077-4893.2.2020.207678 (in Ukrainian).

15. Osinnij zahyst dlja pshenyci. [Autumn protection for wheat]. (2020). Agrobiznes s'ogodni. 4 veresnja. URL: http://agro-business.com.ua/agro/ahronomiia-sohodni/item/18693 (in Ukrainian).

16. Perelik pestycydiv i agrohimikativ, dozvolenyh do vykorystannja v Ukrai'ni. [List of pesticides and agrochemicals approved for use in Ukraine] (2018). JuNIVEST MEDIA, K., 1039 (in Ukrainian).

17. Pisarenko, P. V., Matjuha, V. L., Pisarenko, P. P., \& Antonenko, Ja. V. (2021). Efektivnist' bakovih sumishej pesticidiv proti shkidnikiv ta hvorob u tehnologiï viroshhuvannja pshenici ozimoï v Pivnichnomu Stepu Ukraïni. [Efficiency of tank mixtures of pesticides against pests and diseases in the technology of growing winter wheat in the Northern Steppe of Ukraine]. Visnik PDAA, 1, 80-89 (in Ukrainian). doi: 10.31210/visnyk2021.01.09 
18. Pristac'ka, O. N., Bilovus, G. Ja., \& Vashhishin, O. A. (2021). Vpliv abiotichnih faktoriv ta okremih elementiv tehnologiï na shhil'nist' populjacij fitofagiv u posivah pshenici ozimoï v Zahidnomu Lisostepu Ukraïni. [Influence of abiotic factors and separate elements of technology on the density of phytophagous populations in winter wheat crops in the Western Forest-Steppe of Ukraine]. Peredgirne ta girs'ke zemlerobstvo i tvarinnictvo, 69(2), 91-107 (in Ukrainian). doi: 10.32636/01308521.2021-(69)-2-6

19. Sahnenko, V. V., \& Sahnenko, D. V. (2018). Osoblyvosti rozmnozhennja shkidnykiv pshenyci ozymoi' pry resursooshhadnyh systemah zastosuvannja dobryv u Lisostepu Ukrai'ny. [Peculiarities of reproduction of winter wheat pests in resource-saving systems of fertilizer application in the Forest-Steppe of Ukraine]. Visnyk Poltavs'koi' DAA. 3. 45-49 (in Ukrainian).

20. Sahnenko, V. V., \& Sahnenko, D. V. (2020) Obґruntuvannja biologichnih i himichnih zahodiv shhodo kontrolju kompleksu fitofagiv na pshenici ozimij u Lisostepu Ukraïni. [Substantiation of biological and chemical measures to control the complex of phytophages on winter wheat in the Forest-Steppe of Ukraine] Tavrijs'kij naukovij visnik, 111, 131-136 (in Ukrainian). doi: 10.32851/2226-0099.2020.111.18

21. Sekun, M. P., Vlasova, O. G., \& Berezovs'ka-Brigas, V. V. (2019). Monitoring formuvannja rezistentnosti populjacij shkidnikiv sil's'kogospodars'kih kul'tur do insekticidiv. [Monitoring the formation of resistance of crop pest populations to insecticides]. Zahist i karantin roslin, 65, 149-160. doi: 10.36495/1606-9773.2019.65.149-160

22. Strigun, O. O., \& Suddenko, Ju. M. (2016). Vidovij sklad shkidlivoï entomofauni agrobiocenozu pshenici ozimoï v Pravoberezhnomu Lisostepu Ukraïni. [Species composition of harmful entomofauna of winter wheat agrobiocenosis in the Right-Bank Forest-Steppe of Ukraine]. Visnik Poltavs'koï derzhavnoï agrarnoï akademiï. 3, 15-18 (in Ukrainian).

23. Suchasnyj zahyst zernovyh kolosovyh kul'tur vid shkidnykiv. [Modern protection of cereals from pests] (2019). Agronom. 18 bereznja URL: https://www.agronom.com.ua/zahyst-zernovyh-kolosovyh-kultur-vid-shkidnykiv/ 4296 (in Ukrainian).

24. Shkidnyky i hvoroby ozymyh zernovyh: potochna sytuacija. [Pests and diseases of winter cereals: the current situation]. (2019). Propozycija. 16 travnja. URL: https://propozitsiya.com/ua/shkidnyky-i-hvoroby-ozymyh-zernovyhpotochna-sytuaciya/ 4010 (in Ukrainian).

25. Shahova, N. M., \& Kocjurubenko, N. I. (2012). Zahyst ozymoi' pshenyci vid sysnyh shkidnykiv. [Protection of winter wheat from sucking pests]. Naukovo-metodychnyj zhurnal «Naukovi praci». Serija «Ekologija». Tom 179. 167. $146-150$ (in Ukrainian).

26. Varchenko, T., Dolja, M. M., Nemeric'ka, L., \& Zhuravs'ka, I. (2017). Osoblivosti formuvan' shkidlivih organizmiv pri resursooshhadnih tehnologijah zahistu sil's'kogospodars'kih kul'tur u Lisostepu i Polissi Ukraïni. [Peculiarities of pest formation in resource-saving technologies of crop protection protection in the Forest-Steppe and Polissya of Ukraine]. Agrarna nauka ta osvita Podillja: zbirnik naukovih prac' mizhnar. nauk.-prakt. konf. Ch.1. (14-16 bereznja 2017 r., m. Kam'janec'-Podil's'kij). Ternopil' : Krok, 2017, 173-175 (in Ukrainian).

27. Vinnichuk, T. S., Parmins'ka, L. M., \& Gavryljuk, N. M. (2016). Zahyst pshenyci ozymoi' vid hvorob ta shkidnykiv za riznyh system udobrennja. [Protection of winter wheat from diseases and pests under various fertilizer systems]. Visnyk agrarnoi' nauky. 9. 30-34 (in Ukrainian).

28. Zahyst ozymoi' pshenyci vid shkidnykiv. [Protection of winter wheat from pests]. (2020). Avgust. 13 travnja. URL: http://ua.avgust.com /zahist_ozimoi_pshenici_vid_shkidnikiv (in Ukrainian).

Demenko V. M., PhD (Agricultural Sciences), Assistant Professor, Sumy National Agrarian University, Sumy, Ukraine

Golinach O. L., Head of the phytosanitary safety department of the Main department of the State Consumer Service in Sumy region, Sumy, Ukraine

Yemets O. M., PhD (Biological Sciences), Assistant Professor, Sumy National Agrarian University, Sumy, Ukraine

Burdulanyuk A. O., PhD (Agricultural Sciences), Assistant Professor, Sumy National Agrarian University, Sumy, Ukraine

Rozhkova T. O., PhD (Biological Sciences), Assistant Professor, Sumy National Agrarian University, Sumy, Ukraine

Tatarynova V. I., PhD (Agricultural Sciences), Assistant Professor, Sumy National Agrarian University, Sumy, Ukraine

The dynamics reflecting the number of winter wheat pests in the conditions of Sumy region

The research was conducted in the basic husbandries of the phytosanitary safety department of the main department of the State Food and Consumer Service in Sumy region in 2016-2018. The method of the research was general. Winter wheat crops damages are caused by scarab beetle (Anisoplia austriaca Hrbst.), cereal chafer (Anisoplia segetum Hrbst.), oat leaf beetle (Oulema melanopus L.), blue cereal leaf beetle (Oulema lichenis Voet.), barley flea beetle (Phyllotreta vittula Redt.), corn ground beetle (Zabrus tenebrioides Goeze), Bishop's Mitre (Aelia acuminata L.), sunn pest (Eurygaster integriceps Put.), wheat aphid (Schizaphis graminum Rond.), wheat thrips (Haplothrips tritici Kurd.), Hessian fly (Mayetiola destructor Say), frit fly (Oscinella pusilla Mg.).

The scarab beetle is widespread in the Sumy region, and the cereal chafer is more common in the Polissya region. Bread beetle larvae inhabited $22.7 \%$ of winter wheat areas in 2016, $20.3 \%$ in 2017, and 23,9 \% in 2018. The average number of larvae of bread beetles in 2016, 2018 was 0,7 specimens per $m^{2}$, in $2017-0,9$ specimens per $m^{2}$. The most common in wheat crops were adults of bread beetles, which in the phase of milk-wax ripeness gnawed the grain and pushed the grain out of the ear. Bread beetles in the phase of milk ripeness of grain inhabited in 2016 85,2\% of the surveyed areas of winter wheat, in $2017-84,6 \%$, in $2018-72.4 \%$. The number of adult grain beetles was 0,3 specimens per $\mathrm{m}^{2}$ in 2016 , in 2017 0.4 specimens per $m^{2}$, in $2018-0.6$ specimens per $m^{2}$.

Due to feeding on the grain of larvae and bugs, winged eels of the Bishop's Mitre and sunn pest, the baking and nutritional qualities of flour, as well as sowing qualities of grain deteriorate. Bread bugs inhabited $24,1 \%$ of surveyed areas of winter wheat in $2016,37.1 \%$ in 2017, and $42.3 \%$ in 2018. The average number of bread bugs on winter wheat crops was 0,7 specimens per $m^{2}$.

In 2016-2017, the number of larvae of the frit fly in the autumn was 1.4 specimens per $m^{2}$, and in 2018 increased to 2.0 specimens per $m^{2}$. The number of larvae of the Hessian fly in 2016-2017 was 1.3 specimens per $m^{2}$, in $2018-$ 1.5 specimens per $m^{2}$.

Key words: winter wheat, scarab beetle, cereal chafer, Bishop's Mitre, sunn pest, Hessian fly, the number of pests, the percentage of inhabited areas by pests. 